\title{
ANALISIS PENGARUH KEPERCAYAAN, KEKUATAN MEREK (BRAND EQUITY), KEPUASAN DAN KUALITAS LAYANAN TERHADAP
}

\author{
Yuniar Eko Pramono
}

\begin{abstract}
This study aims to determine Is the confidence, the strength of the brand (brand equity), satisfaction and service quality significantly influence consumer purchasing decisions lightweight steel roof truss (Pryda) Raka Mitra Jaya CV and analyze which of the dominant variable influencing consumer purchasing decisions. The population in this study is a customer $\mathrm{CV}$. Raka Mitra Jaya taken as many as 63 respondents using simple random sampling technique sampling technique based on respondents who had ever bought a product steel roof truss (Pryda) CV Raka Mitra Jaya. Based on the research results, obtained the following regression equation: $\mathrm{Y}=0,136 \mathrm{X} 1+0,177 \mathrm{X} 2+0,107 \mathrm{X} 3+0,062 \mathrm{X} 4$. Based on statistical data analysis, indicators in this study are valid and are reliable variables. In the analytical testing validity, reliability and regression analysis. Calculation or testing the hypothesis by using statistical computer program SPSS 17.00. Individual sequence of each variable is the variable most influential brand power with a regression coefficient of 0.177 , confidence with a regression coefficient of 0.136 , satisfaction with a regression coefficient of 0.107 and quality service with a regression coefficient of 0.062 . This research is the dominant variable is the strength of the brand, with the results of the regression of 0.177 . The research results that all independent variable positive and significant impact on purchasing decisions through $\mathrm{F}$ test.
\end{abstract}

Keywords: confidence, strength of the brand (brand equity), satisfaction, quality service and purchasing decisions

\section{LATAR BELAKANG}

Perilaku pembelian seseorang dapat dikatakan sesuatu yang unik, karena preferensi dan sikap terhadap obyek setiap orang berbeda. Selain itu konsumen berasal dari beberapa segmen, sehingga apa yang diinginkan dan dibutuhkan juga berbeda. Terdapat banyak faktor yang berpengaruh terhadap keputusan pembelian. Fenomena tersebut dapat dilihat dari kondisi persaingan saat ini yang terjadi pada produk rangka atap baja ringan pengganti rangka atap rumah atau bangunan dari kayu. Keanekaragaman produk rangka atap baja ringan yang ada pada saat ini mendorong konsumen untuk melakukan identifikasi dalam pengambilan keputusan saat menentukan suatu merek yang menurut mereka memenuhi kriteria sebuah produk rangka atap baja ringan yang ideal dan bernilai tinggi.

Kompetisi tersebut akan terus berlanjut karena beberapa merek baru terus bermunculan dengan berbagai macam varian seperti: Tangso, Bali Trust, Gigasteel, Galvasteel, Sky Truss dll. Perkembangan merek rangka atap baja ringan mudah yang pada waktu ini sudah 


\section{JURNAL MANAJEMEN VOL. 5 NO. 2 DESEMBER 2015}

terdaftar banyaknya merk ( belum terhitung merk lokal yang tidak mendaftarkan merk nya dengan resmi ). Mengenai pengaruh kepercayaan, kekuatan merek (brand equity), kepuasan, dan kualitas layanan terhadap keputusan pembelian. CV RAKA MITRA JAYA adalah perusahaan agen penjual dan sebagai prefabrikasi yang bergerak di bidang kontruksi rangka atap baja ringan pengganti rangka atap dari kayu. CV RAKA MITRA JAYA dengan menggunakan merek PRYDA dan sistem software PYRDA ROOF. Sejak didirikannya perusahaan ini yang bergerak di bidang kontruksi yang termasuk bagian dari sebuah bangunan yaitu atap yang digunakan untuk bangunan di era jaman modern ini yang sangat cocok dipergunakan di Indonesia yang dimana solusi pengganti kayu. CV RAKA

\section{TINJAUAN PUSTAKA DAN \\ HIPOTESIS}

\section{Pemasaran}

Menurut Rangkuti (2009, hal. 38) mendefinisikan bahwa : "Pemasaran adalah proses perencanaan dan menjalankan konsep, harga, promosi serta distribusi sejumlah barang dan jasa untuk menciptakan pertukaran yang mampu memuaskan tujuan individu dan organisasi “. Subagyo (2010, hal. 2) sebagai berikut :
MITRA JAYA berdiri sebagai perusahaan agen penjual mengembang bisnis di bidang kontruksi rangka atap baja ringan, dalam pemasaran produk meliputi wilayah Jawa Tengah ( seperti Klaten, Solo, Karanganyar, Boyolali, Purbalingga, Magelang ) dan wilayah Daerah Istimewa Yogyakarta, juga sudah sampai wilayah Jawa Timur yaitu Pacitan. Pada saat ini CV. RAKA MITRA JAYA telah melakukan strategi yang sudah bagus, akan tetapi banyak pesaing terdekat, pesaing lama dan baru yang bergerak di bidang yang sama menjadi penghalang bagi perusahaan. Disebabkan masih besarnya pasar yang tersedia dan di masa sekarang produk rangka atap baja ringan menjadi peluang bisnis yang menguntungan bagi setiap pelaku bisnis, Oleh sebab itu persaingan semakin ketat.

“ Pemasaran adalah sebagai proses sosial dan manajeriual dimana individu dan kelompok memperoleh apa yang mereka butuhkan dan inginkan melalui penciptaan dan pertukaran produk serta nilai dengan pihak lain ".

Proses pemasaran itu dimulai jauh sebelum barang-barang di produksi. Keputusan-keputusan dalam pemasaran itu harus dibuat untuk menentukan produk serta pasarnya, penentuan harga, dan 
kegiatan promosi. Kegiatan pemasaran tidak hanya berupa pertukaran berupa uang, tapi mencakup distribusi sejumlah ide maupun jasa yang dapat memberikan kebutuhan dan kepuasan kepada individu dan organisasi sehingga segala usaha perusahaan dapat terus berjalan dan mendapat pandangan yang baik dari konsumen terhadap perusahaan.

\section{Perilaku Konsumen}

Menurut Kottler (2009 : 166) perilaku konsumen adalah studi tentang bagaimana individu, kelompok, dan organisasi memilih, membeli, menggunakan, dan bagaimana barang, jasa, ide, atau pengalaman untuk memuaskan kebutuhan dan keinginan mereka. menurut Setiadi (2008 : 3) perilaku konsumen adalah tindakan yang terlibat langsung dalam mendapatkan, mengkonsumsi, dan menghabiskan produk atau jasa, termasuk proses yang mendahului dan menyusuli tindakan ini.

Menurut kotler dan keller (2009 : 166 - 183), Perilaku pembelian konsumen dipengaruhi oleh faktor budaya, sosial, pribadi dan psikologis.

\section{Keputusan Pembelian}

Menurut Salusu (2003, hal. 47) dalam kutipan ST.Nafillah.2012 mengemukakan bahwa: "Pengambilan keputusan ialah proses memilih suatu alternatif cara bertindak dengan metode yang efisien sesuai situasi." Selanjutnya Amirullah (2002, hal. 61) dalam kutipan ST.Nafillah.2012 bahwa : "Pengambilan keputusan adalah suatu proses penilaian dan pemilihan dari berbagai alternatif sesuai dengan kepentingan-kepentingan tertentu dengan menetapkan suatu pilihan yang dianggap paling menguntungkan." Ada beberapa hal yang dipertimbangkan ketika seseorang mengambil keputusan pembelian. Diantaranya adalah: Kepercayaan, Kekuatan Merek, Kepuasan, Kualitas layanan

\section{Hubungan Kepercayaan (Trust) dengan Keputusan Pembelian}

Pihak penjual harus menganut kepuasan pelanggan (costumer satisfaction) supaya dapat memepertahankan hubungan jangka panjang dengan para pembelinya. Agar dapat bertahan hidup didalam era persaingan yang ketat, pihak penjual harus memiliki pelanggan yang loyal (customer loyality) yang percaya terhadap keunggulan dari produk tersebut. Setiap konsumen memiliki tingkat kepercayaan yang berbeda ada yang memiliki tingkat kepercayaan lebih tinggi dan ada pula yang memiliki tingkat kepercayaan yang lebih rendah. Hal tersebut disebabkan oleh kepercayaan konsumen menyangkut kepercayaan bahwa suatu produk memiliki berbagai atribut dan manfaat dari berbagai 


\section{JURNAL MANAJEMEN VOL. 5 NO. 2 DESEMBER 2015}

atribut tersebut. Kepercayaan konsumen terhadap suatu produk, atribut dan manfaat produk menggambarkan persepsi konsumen.

$H 1$ : Kepercayaan (Trust) berpengaruh positif terhadap keputusan pembelian

\section{Hubungan Kekuatan Merek (Brand} Equity) dengan Keputusan Pembelian

Menciptakan kesan menjadi salah satu karateristik dasar dalam orientasi pemasaran modern yaitu lewat pemberian perhatian lebih serta menciptaan merek yang kuat. Implikasi dari hal tersebut menjadikan merek suatu produk menciptakan image dari produk itu sendiri di benak pikiran konsumen dan menjadikan motivasi dasar bagi konsumen dalam memilih suatu produk (http//google.com).

Atas dasar pemikiran tersebut, maka dapat dirumuskan hipotesis :

H2 : Brand Equity berpengaruh positif terhadap keputusan pembelian konsumen.

\section{Hubungan Kepuasan dengan}

\section{Keputusan Pembelian}

Kepuasan pelanggan memacu pada saat tertentu saja dimana suatu layanan

\section{METODE PENELITIAN}

Variabel penelitian antara lain:

a. Kepercayaan $\left(\mathrm{X}_{1}\right)$ diberikan atas dari awal hingga akhir suatu layanan diberikan, kepuasan layanan langsung terlihat dari seberapa suka atau tidaknya konsumen terhadap layanan yang didapat. Kepuasan layanan secara keseluruhan layanan yang diberikan suatu lembaga layanan. Jadi dengan kualitas pelayanan yang diberikan perusahaan jika diterapkan dengan baik maka akan tercipta kepuasan pada pelanggan.

Berdasarkan landasan teori serta uraian dan kerangka konseptual di atas maka hipotesis dalam penelitian ini adalah sebagai berikut:

H3 : Kepuasan berpengaruh positif terhadap keputusan pembelian

\section{Hubungan Kualitas Layanan dengan keputusan pembelian}

Nasution (2004:50) berpendapat ba hwakualitas layanan merupakan penilaian menyeluruh atas keunggulan suatu layanan. Bila penilaian yang dihasilkan merupakan penilaian yang positif, maka kualitas layananini akan berdampak pada terjadinya keputusan pembelian. Dari uraian diatas dapat dirumuskan hipotesis:

H4 : Kualitas pelayanan berpengaruh positif terhadap keputusan pembelian.

Kepercayaan adalah persepsi konsumen atas perilaku yang dapat diketahui dengan koesionaer dan mengukur jawaban 
dalam skala ordinal mengenai kepercayaan. Indikator-indikator tersebut antara lain :

1) Konsisten dalam kualitas dan pelayanan.

2) Dapat memenuhi kebutuhan dan keinginan pelanggan

3) Yakin bahwa CV. Raka Mitra Jaya dapat dipercaya.

4) Dapat diandalkan. (item diadaptasi dan dimodifikasi dari

Einwiller(2003),Jarvenpaa (2000), Garbarino,Lee (2003)

b. Kekuatan Merek ( Brand Equity ) ( $\mathrm{X}_{2}$ )

Kekuatan merek adalah persepsi konsumen atas perilaku yang dapat diketahui dengan koesionaer dan mengukur jawaban dalam skala ordinal mengenai kekuatan merek. Indikatorindikator tersebut antara lain:

1) Memiliki keunikan dibandingkan dengan merek lain.

2) Memiliki kualitas merek baik.

3) Fitur bahan dan campuran lebih baik dibandingkan merek lain

4) Memiliki nilai lebih, dibandingkan merek lain. (item diadaptasi dan dimodifikasi dari Aaker.1996a dan 1996b)

c. Kepuasan $\left(\mathrm{X}_{3}\right)$

Kepuasan adalah persepsi konsumen atas perilaku yang dapat diketahui dengan koesionaer dan mengukur jawaban dalam skala ordinal mengenai kepuasan. Indikator-indikator tersebut antara lain :

1) Memberi rasa puas

2) Sangat bijaksana.

3) Menjadikan pengalaman tersendiri

4) Merekomendasikan teman. (Byoungsoo Kim.2012)

d. Kualitas Layanan $\left(\mathrm{X}_{4}\right)$

Kualitas layanan adalah persepsi konsumen atas perilaku yang dapat diketahui dengan koesionaer dan mengukur jawaban dalam skala ordinal mengenai kualitas layanan. Indikatorindikator tersebut antara lain

1) Layanan personil

2) Dapat memahami kebutuhan pelanggan.

3) Layanan pribadi.

4) Pengiriman produk ini tepat waktu. (Heidi Chan, Bonny Kwan and Derry Law.2011)

e. Keputusan Pembelian ( Y ) 


\section{JURNAL MANAJEMEN VOL. 5 NO. 2 DESEMBER 2015}

Keputusan Pembelian

adalah persepsi konsumen atas perilaku yang dapat diketahui dengan koesionaer dan mengukur jawaban dalam skala ordinal mengenai Keputusan Pembelian. Indikator keputusan pembelian $(Y)$ antara lain :

1) Keyakinan membeli

2) Mempertimbangkan produk

3) Prioritas pembelian

4) Merekomendasikan produk. (Chun-Chen Huang, Szu-Wei Yen.2014)

\section{HASIL DAN PEMBAHASAN}

Teknik pengujian menggunakan korelasi Product Moment Pearson dengan ketentuan $\mathrm{r}$ hitung lebih besar dari $\mathrm{r}$ tabel

maka butir koesioner dikatakan valid dan

Dalam penelitian ini populasinya adalah konsumen yang membeli atau menggunakan produk rangka baja ringan ( PRYDA ) di CV. RAKA MITRA JAYA yang total jumlah populasinya 170 orang, yang didapat dari data sekunder yaitu data onwer atau konsumen tahun 2013 sampai 2015. Metode pengumpulan data dalam penelitian ini adalah menggunakan teknik kuesioner (daftar pertanyaan). begitu juga sebaliknya bila $r$ hitung lebih kecil dari $r$ tabel maka butir koesioner tidak valid sebagai instrumen penelitian.

\begin{tabular}{|c|c|c|c|}
\hline Item & $\mathrm{r}_{\text {hitung }}$ & $\mathrm{r}_{\text {tabel }}$ & Keterangan \\
\hline 1 & 0,724 & 0,2480 & Valid \\
\hline 2 & 0,714 & 0,2480 & Valid \\
\hline 3 & 0,823 & 0,2480 & Valid \\
\hline 4 & 0,589 & 0,2480 & Valid \\
\hline
\end{tabular}

Data olah ( 2015 )

Hasil Uji Validitas Intrumen Kekuatan Merek ( Brand Equity )

\begin{tabular}{|c|c|c|c|}
\hline Item & $\mathrm{r}_{\text {hitung }}$ & $\mathrm{r}_{\text {tabel }}$ & Keterangan \\
\hline 1 & 0,707 & 0,2480 & Valid \\
\hline 2 & 0,716 & 0,2480 & Valid \\
\hline 3 & 0,821 & 0,2480 & Valid \\
\hline 4 & 0,632 & 0,2480 & Valid \\
\hline
\end{tabular}

Data olah ( 2015) 
Hasil Uji Validitas Intrumen Kepuasan

\begin{tabular}{|c|c|c|c|}
\hline Item & $\mathrm{r}_{\text {hitung }}$ & $\mathrm{r}_{\text {tabel }}$ & Keterangan \\
\hline 1 & 0,686 & 0,2480 & Valid \\
\hline 2 & 0,836 & 0,2480 & Valid \\
\hline 3 & 0,853 & 0,2480 & Valid \\
\hline 4 & 0,910 & 0,2480 & Valid \\
\hline
\end{tabular}

Data olah (2015)

Hasil Uji Validitas Intrumen Kualitas Layanan ( Service Quality )

\begin{tabular}{|c|c|c|c|}
\hline Item & $\mathrm{r}_{\text {hitung }}$ & $\mathrm{r}_{\text {tabel }}$ & Keterangan \\
\hline 1 & 0,700 & 0,2480 & Valid \\
\hline 2 & 0,710 & 0,2480 & Valid \\
\hline 3 & 0,873 & 0,2480 & Valid \\
\hline 4 & 0,649 & 0,2480 & Valid \\
\hline
\end{tabular}

Data olah ( 2015)

Hasil Uji Validitas Intrumen Keputusan Pembelian

\begin{tabular}{|c|c|c|c|}
\hline Item & $\mathrm{r}_{\text {hitung }}$ & $\mathrm{r}_{\text {tabel }}$ & Keterangan \\
\hline 1 & 0,727 & 0,2480 & Valid \\
\hline 2 & 0,736 & 0,2480 & Valid \\
\hline 3 & 0,843 & 0,2480 & Valid \\
\hline 4 & 0,773 & 0,2480 & Valid \\
\hline
\end{tabular}

Data olah (2015)

Dari data tabel tersebut pada tabel 4.7 sampai tabel 4.11 menjelaskan bahwa butir-butir kuesioner dalam penelitian ini adalah valid dikarenakan nilai $\mathrm{r}$ hitung pada masing-masing butir lebih besar dari r tabel yaitu 0,2480 .

\section{Analisis Uji Reliabilitas}

Dari hasil reliabelitas dengan menggunakan metode alpha Cronbach menunjukan bahwa peubah yang memiliki nilai Cronbach's Alpha seperti dalam Tabel Uji reliabilitas pada penelitian ini menggunakan metode alpha Cronbach untuk menentukan apakah setiap instrumen reliabel atau tidak. 


\section{JURNAL MANAJEMEN VOL. 5 NO. 2 DESEMBER 2015}

Hasil Uji Relibilitas

\begin{tabular}{|lcc|}
\hline \multicolumn{1}{|c|}{ Item Kuesioner } & Alpha Cronbach & Keterangan \\
\hline Kepercayaan & 0,677 & Reliabel \\
Kekuatan Merek (Brand Equity) & 0,686 & Reliabel \\
Kepuasan & 0,842 & Reliabel \\
Kualitas Layanan & 0,769 & Reliabel \\
Keputusan Pembelian & 0,709 & Reliabel \\
\hline
\end{tabular}

Data olah (2015)

Dari Nilai Alpha Cronbach kurang dari 0,61 s.d 0,80 sebagaimana yang tercantum dalam tabel 4.12 tersebut, sehingga dapat disimpulkan seluruh item pertanyaan dalam penelitian ini adalah reliabel atau konsisten.

\section{Analisis Regresi Berganda}

\begin{tabular}{|c|c|c|c|c|c|c|}
\hline \multicolumn{7}{|c|}{ Coefficients $^{\mathrm{a}}$} \\
\hline \multirow[b]{2}{*}{ Model } & & \multicolumn{2}{|c|}{ Unstandardized Coefficients } & $\begin{array}{l}\text { Standardized } \\
\text { Coefficients }\end{array}$ & & \\
\hline & & B & Std. Error & Beta & $\mathrm{t}$ & Sig. \\
\hline 1 & (Constant) & 9.730 & 1.557 & & 6.251 & .000 \\
\hline & Kepercayaan & .136 & .218 & .164 & .623 & .535 \\
\hline & Kekuatan Merek & .177 & .238 & .216 & .744 & .460 \\
\hline & Kepuasan & .107 & .102 & .139 & 1.053 & .297 \\
\hline & Kualitas Layanan & .062 & .125 & .080 & .497 & .621 \\
\hline
\end{tabular}

a. Dependent Variable: Keputusan Pembelian

Dari hasil tersebut apabila ditulis coefficient sebagai berikut :

persamaan regresi dalam bentuk

standardized

$$
\begin{gathered}
\mathrm{Y}=0,136 \mathrm{X} 1+0,177 \mathrm{X} 2+0,107 \mathrm{X} 3+ \\
0,062 \mathrm{X} 4
\end{gathered}
$$

Nilai koefisien kepercayaan untuk variabel X1 sebesar 0,136. Hal ini

Persamaan regresi berganda tersebut dijelaskan sebagai berikut :
a) Kepercayaan
$\left(\mathrm{X}_{1}\right) \quad$ terhadap
kepututsan pembelian (Y) mengandung arti bahwa setiap kenaikan kekuatan merek satu satuan maka variabel kepetusan pembelian (Y) akan 
naik sebesar 0,136 dengan asumsi bahwa variabel bebas yang lain dari model regresi adalah tetap.

Nilai koefisien kekuatan merek untuk variabel $\mathrm{X}_{2}$ sebesar 0,177 . Hal ini mengandung arti bahwa setiap kenaikan kekuatan merek satu satuan maka variabel kepetusan pembelian (Y) akan naik sebesar 0,177 dengan asumsi bahwa variabel bebas yang lain dari model regresi adalah tetap.

b) Kepuasan $\left(\mathrm{X}_{3}\right)$ terhadap keputusan pembelian $(\mathrm{Y})$

Nilai koefisien kepuasan terstandarisasi untuk variabel kepuasan $\left(\mathrm{X}_{3}\right)$ sebesar 0,107 . Hal e) variabel bebas yang lain dari model regresi adalah tetap. ini mengandung arti bahwa setiap kenaikan kepuasan satu satuan maka variabel kepetusan pembelian (Y) akan naik sebesar 0,107 dengan asumsi bahwa variabel bebas yang lain dari model regresi adalah tetap.

c) Kualitas layanan $\left(\mathrm{X}_{4}\right)$ terhadap keputusan pembelian (Y)

d) Nilai koefisien kepuasan terstandarisasi untuk variabel kepuasan $\left(\mathrm{X}_{3}\right)$ sebesar 0,062. Hal ini mengandung arti bahwa setiap kenaikan kepuasan satu satuan maka variabel kepetusan pembelian (Y) akan naik sebesar 0,062 dengan asumsi

bahwa

ANOVA $^{b}$

\begin{tabular}{|l|r|r|r|r|rr|}
\hline Model & \multicolumn{1}{|c|}{$\begin{array}{c}\text { Sum of } \\
\text { Squares }\end{array}$} & df & \multicolumn{1}{c|}{$\begin{array}{c}\text { Sean } \\
\text { Square }\end{array}$} & \multicolumn{1}{|c|}{ F } & \multicolumn{2}{|c|}{ Sig. } \\
\hline 1 Regression & 127.091 & 4 & 31.773 & 5.110 & $.000^{\mathrm{a}}$ \\
Residual & 360.623 & 58 & 6.218 & & \\
Total & 487.714 & 62 & & & & \\
\hline
\end{tabular}

a. Predictors: (Constant), Kualitas Layanan, Kepuasan, Kepercayaan, Kekuatan Merek

b. Dependent Variable: Keputusan Pembelian

Berdasarkan hasil uji ANOVA lebih besar dari 2,76) dan tingkat pada Tabel 4.34 didapatkan $\mathrm{F}$ hitung sebesar 5,110 dengan tingkat signifikansi 0,000. Karena $\mathrm{F}$ hitung $>\mathrm{F}$ tabel $(5,110$ signifikansi $0,000<0,05$ maka semua variabel (kepercayaan, kekuatan merek, kepuasan, kualitas layanan) secara 


\section{JURNAL MANAJEMEN VOL. 5 NO. 2 DESEMBER 2015}

bersama-sama berpengaruh signifikan Berdasarkan analisis data maka dapat dikemukakan beberapa temuan hasil penelitian sebagai berikut:

1. Variabel kekuatan merek memiliki pengaruh lebih besar terhadap keputusan pembelian konsumen dibandingkan variabel lainnya dengan hasil regresi sebesar 0,177.

3. kepercayaan merupakan salah satu variabel yang dapat berpengaruh kepada konsumen untuk melakukan pembelian produk rangka atap baja ringan (PRYDA).

4. Hipotesis kedua $\left(\mathrm{H}_{2}\right)$ yang menyatakan bahwa kekuatan merek (X2) berpengaruh positif terhadap keputusan pembelian (Y), telah terbukti kebenarannya. Hal ini berarti kekuatan merek merupakan salah satu variabel yang berpengaruh kepada konsumen untuk melakukan pembelian produk rangka atap baja ringan (PRYDA).

5. Hipotesis kedua $\left(\mathrm{H}_{3}\right)$ yang menyatakan bahwa kepuasan (X3) berpengaruh positif terhadap keputusan pembelian (Y), telah terbukti kebenarannya. Hal ini berarti kepuasan merupakan salah satu variabel yang berpengaruh kepada konsumen untuk terhadap Keputusan pembelian ( Y ).

2. Hipotesis pertama $\left(\mathrm{H}_{1}\right)$ yang menyatakan bahwa kepercayaan (X1) berpengaruh positif terhadap keputusan pembelian (Y), telah terbukti kebenarannya. Hal ini berarti

melakukan pembelian produk rangka atap baja ringan $(P R Y D A)$.

6. Hipotesis kedua $\left(\mathrm{H}_{4}\right)$ yang menyatakan bahwa kualitas layanan (X4), berpengaruh positif terhadap keputusan pembelian (Y), telah terbukti kebenarannya. Hal ini berarti kualitas layanan merupakan salah satu variabel yang berpengaruh kepada konsumen untuk melakukan pembelian produk rangka atap baja ringan (PRYDA).

Berdasarkan hasil pengujian dapat diketahui bahwa variabel kekuatan merek (Brand Equity) adalah paling dominan terhadap keputusan pembelian rangka atap baja ringan (PRYDA). Hal ini ditunjukan pada uji koefisien dengan nilai kekuatan merek memiliki pengaruh lebih besar terhadap keputusan pembelian konsumen dibandingkan variabel lainnya dengan hasil regresi sebesar 0,177. Hasil analisis yang telah dilakukan dalam penelitian ini 
sudah memenuhi uji persyaratan analisis regresi linear berganda. Data yang dikumpulkan melalui kuesioner yang disebarkan kepada responden telah diuji validitas dan reliabilitasnya sehingga dapat dilanjutkan pada pengujian asumsi klasik yaitu uji F. hasil pengujian hipotesis menunjukkan $\mathrm{F}$ hitung sebesar 5,110 dengan tingkat signifikansi 0,000. Karena $\mathrm{F}$ hitung $>\mathrm{F}$ tabel $(5,110$ lebih besar dari 2,76) dan tingkat signifikansi $0,000<0,05$ maka semua variabel (kepercayaan, kekuatan merek, kepuasan, kualitas layanan) secara bersama-sama berpengaruh signifikan terhadap Keputusan pembelian.

Secara keseluruhan dari hasil penelitian dapat diketahui peranan dari

\section{KESIMPULAN}

Berdasarkan hasil penelitian mengenai analisis pengaruh kepercayaan, brand equity, kepuasan, kualitas layanan terhadap keputusan pembelian rangaka atap PRYDA CV Raka Mitra Jaya dapat diambil kesimpulan sebagai berikut :

1. Menyatakan bahwa kepercayaan (X1) berpengaruh positif terhadap keputusan pembelian (Y), telah terbukti kebenarannya. Hal ini berarti kepercayaan merupakan salah satu variabel yang dapat berpengaruh kepada konsumen variabel kepercayaan, brand equity dalam peningkatan keputusan pembelian pada suatu produk sangat besar peranannya sehingga diperlukan suatu metode pendekatan yang efektif dan tepat serta perhatian yang lebih dari perusahaan dalam memenuhi kebutuhan dan keinginan konsumennya sehingga dapat mencapai keuntungan bagi perusahaan. Dengan demikian hasil penelitian ini diperoleh hasil bahwa variabel kepercayaan, brand equity berpengaruh terhadap peningkatan keputusan pembelian konsumen. CV. Raka Mitra Jaya perlu mempertahankan variabel - variabel yang sudah dinilai baik oleh pelanggan serta perlu memperbaiki hal-hal yang masih kurang.

untuk melakukan pembelian produk rangka atap baja ringan (PRYDA).

2. Menyatakan bahwa kekuatan merek (X2) berpengaruh positif terhadap keputusan pembelian (Y), telah terbukti kebenarannya. Hal ini berarti kekuatan merek merupakan salah satu variabel yang berpengaruh kepada konsumen untuk melakukan pembelian produk rangka atap baja ringan (PRYDA). 


\section{JURNAL MANAJEMEN VOL. 5 NO. 2 DESEMBER 2015}

3. Menyatakan bahwa kepuasan (X3) berpengaruh positif terhadap keputusan pembelian (Y), telah terbukti kebenarannya. Hal ini berarti kepuasan merupakan salah satu variabel yang berpengaruh kepada konsumen untuk melakukan pembelian produk rangka atap baja ringan (PRYDA).

4. Menyatakan bahwa kualitas layanan (X4), berpengaruh positif terhadap keputusan pembelian (Y), telah terbukti kebenarannya. Hal ini berarti kualitas layanan merupakan salah satu variabel yang berpengaruh kepada konsumen

\section{DAFTAR PUSTAKA}

Ahmad, Subagio. 2010. Marketing In Business. Mitra Wacana Media: Jakarta Augusty, Ferdinand. 2006. Metodologi Penelitian Manajemen. Edisi 2.: Badan Penerbit Universitas Diponegoro: Semarang

Anandya Cahya Hardiawan. 2013. Pengaruh Kepercayaan, Kemudahan, dan Kualitas Informasi Terhadap Keputusan Pembelian Secara Online.UNDIP

Byoungsoo Kim.2012. Understanding Key Factors of Users' Intentions to Repurchase and Recommend Digital Items in Social Virtual Worlds: South Korea

Chun-Chen Huang, Szu-Wei Yen,PeiChen Huang.2014. The Relationship Among

Corporate Social Responsibility, Service Quality, Corporate Image And Purchase Intention untuk melakukan pembelian produk rangka atap baja ringan (PRYDA)

5. Dari hasil penelitian ini diketahui bahwa variabel kekuatan merek (Brand Equity) adalah paling dominan terhadap keputusan pembelian rangka atap baja ringan (PRYDA). Hal ini ditunjukan pada uji koefisien dengan nilai kekuatan merek memiliki pengaruh lebih besar terhadap keputusan pembelian konsumen dibandingkan variabel lainnya dengan hasil regresi sebesar 0,177 .

Ghozali, Imam. 2009. Aplikasi Multivariate Dengan Program SPSS. Badan Penerbit Universitas Diponegoro: Semarang

J. Setiadi, Nugroho. (2008). Perilaku Konsumen. Kencana: Jakarta

Kotler, Philip. (2009). Manajemen Pemasaran. Edisi 13. Pearson Education Inc, New Jersey

Kotler, Philip. 2009. Manajemen Pemasaran. Erlangga: Jakarta

Mas'ud, Fuad. (2004). Survai diagnosis organisasional: konsep \& aplikasi. Badan Penerbit Universitas Diponegoro: Semarang

Nisfiannoor, Muhammad. 2009. Pendekatan Statistika Modern untuk Ilmu Sosial. Salemba Humatika. Jakarta

Okky Wenkyca Widodo. 2012. Analisis Pengaruh Kualitas Produk, Kualitas Layanan, Dan Promosi 
Terhadap Kepeutusan Pembelian. UNDIP

Praba Sulistyawati.UNDIP. 2010. Analisi Pengaruh Citra Merek, Dan Kualitas Produk terhadap Keputusan Pembelian. UNDIP

Rutoto, Sabar. 2007. Pengantar Metedologi Penelitian. FKIP: Universitas Muria Kudus

Sugiyono. (2009). Statistik untuk Penelitian. Alfabeda: Bandung

Sugiyono. (2010). Metode Penelitian Pendidikan. Alfabeda: Bandung

Samithamby Senthilnathan and Uthayakumar Tharmi.2012. The Relationship of

Intention

$$
\text { Brand Equity to Purchase }
$$

Yulin Fang, Israr Qureshi, Kai H. Lim, Elaine Ramsey, Patrick McCole.2014. Trust, Satisfaction,And Online Repurchase Intention: The Moderating Role Of Perceived Effectiveness Of E-Commerce Institutional Mechanisms 1 